utilized it was maximal at 11.4 per cent with $P$. soppi, at 7.9 per cent with $A$. nidulans, and at $5 \cdot 6$ per cent with $F$. lini (I). Other moulds are considered worthy of further trial.

\section{Roman Gallery at the Grosvenor Museum, Chester}

As part of a general reorganization of the Grosvenor Museum at Chester, a gallery previously devoted to art has been entirely cased in modern style and now illustrates the Roman army. The collections at Chester are particularly rich in Roman material, and it was decided to illustrate the army, and in particular the legions, with special reference to the Chester fortress. The gallery is a long room of nearly $60 \mathrm{ft}$., and this has been broken up by creating three bays in cases of the shop-window type. This provides a singularly attractive display and provides very useful storage-room. Fluorescent tubes have been used both for the general and individual case lighting. The attention of the visitor is first attracted to a model of a soldier. Then follow panels dealing with a soldier's pay, Samian pottery, tools and equipment, building materials and other objects, leading to a large diorama of the Chester fortress showing its buildings, defences and its relationship to the local topography. The story continues, and to conclude is a final panel illustrating the defences of the Roman Empire.

\section{Electron Microsccpy: Conference in London}

The Joint Commission on Electron Microscopy of the International Council of Scientific Unions is sponsoring an international conference on electron microscopy, to be held in London during July 16-21. The detailed organization is in the hands of a committee comprising the members representing the Electron Microscopy Group of the Institute of Physics and members of the Commission resident in Great Britain. Sessions will be devoted to the following subjects: instruments and associated apparatus; electron optics ; the attainment of very high resolution; reflexion methods ; metallurgical applications industrial and chemical applications; fixation and drying methods ; microanatomy of cilia, etc.; fibrillar structures; structure of cell walls ; internal structure of cells; bacteria; viruses; biological specimen techniques; metallurgical and general specimen techniques; and the effect of electron irradiation on matter. All workers interested in the field may attend the conference; they must register with the joint secretaries before March 1 (fee $£ 2$ ). Papers will be accepted for consideration, and authors should in the first instance make their offers to the secretary of the respective national society of electron microscopy, except that in North America they should send them to Prof. T. F. Anderson, 612 Maloney Building, School of Medicine, University of Pennsylvania, Philadelphia 4, and in countries where there is no national society they should send them to the secretary of the programme committee, Dr. V. E. Cosslett, Cavendish Laboratory, Free School Lane, Cambridge. Notification of all papers should be made not later than March 1 . The official languages of the conference will be English, French and German. An exhibition of electron microscopes, ancillary apparatus and books is being arranged. General correspondence relating to the conference should be addressed to the joint secretaries, Dr. C. E. Challice and Mr. F. W. Cuckow, c/o Institute of Physics, 47 Belgrave Square, London, S.W.1.

\section{Third International Congress of Nutrition, Amsterdam}

THE Third International Congress of Nutrition will be held in Amsterdam during September 13-18 under the auspices of the International Union of Nutritional Sciences. The programme will include sessions on the following topics: overnutrition and disease; nutrition and liver disease; parenteral nutrition; nutrition and the psyche; and non-nutrient foreign chemical substances in foods (intentionsl and unintentional additives). Invitations have already been sent by the local Dutch organizing committee to a number of proposed contributors ; but nutrition workers in Britain, particularly members of the [British] Nutrition Society, who would like to participate in the discussions are invited to submit a title and a short synopsis (not exceeding two hundred words) of their proposed contribution for consideration. These should reach Dr. G. H. Bourne, honorary secretary of the Nutrition Society, Department of Histology, London Hospital Medical College, Turner Street, London, E.1, by February 28. Further information about the International Union of Nutritional Sciences can be obtained from the secretary-general, Dr. L. J. Harris, Dunn Nutritional Laboratory, University Field Laboratories, Milton Road, Cambridge.

\section{International Union of Geodesy and Geophysics: General Assembly in Rome}

ThE International Union of Geodesy and Geophysics will be holding its tenth General Assembly in Rome during September 15-29. The constituent International Associations of Geodesy, Meteorology, Hydrology, Oceanography, Vulcanology, Terrestrial Magnetism and Electricity, and Seismology and the Physics of the Earth's Interior, will meet during the period. Delegates attending are nominated by the national adhering organizations of the Union. British scientists wishing to attend or to read or communicate papers may do so only if sponsored by the Royal Society on the recommenda. tion of the British National Committee for Geodesy and Geophysics. Those wishing to submit papers for the scientific meetings should write to the Assistant Secretary of the Royal Society, Burlington House, London, W.1, not later than March 1.

\section{Training of Biologists}

THe Institute of Biology is arranging a meeting, to be held during April 21-22, to discuss the training of biologists. There will be four sessions : on the teaching of biology in schools to those intending to specialize ; on undergraduate courses at universities ; on biological work in technical colleges; and on postgraduate training. It is hoped that the meeting will attract teachers from schools, technical colleges and universities and representatives of employing bodies. Ample time will be allowed for discussion after the invited papers. A programme will be available early in March from the General Secretary, Institute of Biology, Tavistock House South, Tavistock Square, London, W.C.1.

\section{Chemistry Meetings in Eastern Germany}

THe Chemical Society of the Eastern Zone of Germany has recently issued details of the meetings it proposes to hold this year. The programme opens with a conference in Berlin during February 23-24 on the place of electricity in chemical industry and 